\title{
A Geo-spatial approach for quantifying rooftop photovoltaic energy potential in Karnal smart city, Haryana - A case study
}

\author{
Meenakshi \\ Center of Excellence for Energy and Environmental Studies (CEEES), Deenbandhu Chhotu \\ Ram University of Science and Technology (DCRUST), Sonipat-131039 (Haryana), India \\ Mothi Kumar K. E.* \\ Haryana Space Applications Centre (HARSAC), Citizen Resources Information Department, \\ Govt. of Haryana (CRID), Hisar-125004 (Haryana), India

\section{Nisha Kumari} \\ Center of Excellence for Energy and Environmental Studies (CEEES), Deenbandhu Chhotu \\ Ram University of Science and Technology (DCRUST), Sonipat-131039 (Haryana), India
}

*Corresponding author. Email: kemk@rediffmail.com

\section{Article Info}

https://doi.org/10.31018/ jans.v13i2.2665

Received: April 3, 2021

Revised: May 10, 2021

Accepted: May 17, 2021

\section{How to Cite}

Meenakshi, et al. (2021). A Geo-spatial approach for quantifying rooftop photovoltaic energy potential in Karnal smart city Haryana - A case study. Journal of Applied and Natural Science, 13(2), 512 - 519. https://doi.org/10.31018/jans.v13i2.2665

\begin{abstract}
Solar energy is one of the best sustainable forms of renewable energy. India has a cumulative installed capacity of $9.23 \mathrm{GW}$ of grid-connected solar power and set an ambitious target of attaining $100 \mathrm{GW}$ of solar capacity by 2022, including $40 \mathrm{GW}$ of gridconnected rooftop solar installations well. The present study demonstrates the Geospatial technology to estimate the potential of solar photovoltaic on the rooftops of Karnal city. The satellite data of Sentinel -2 and World View-II data was interpreted so as to extract the building footprints. Digital Elevation Model (DEM) data derived from ALOS (Advanced Land Observing Satellite) PALSAR (2019) data was used to calculate the Global Horizontal Irradiance (GHI). It was calculated that the average annual $\mathrm{GHI}$ varied between $0.79-5.9 \mathrm{kWh} / \mathrm{m}^{2} /$ day. The study revealed maximum $\mathrm{GHI}\left(462 \mathrm{kWh} / \mathrm{m}^{2}\right)$ was recorded during the monsoon season. It was estimated that the seasonal energy generation capacity in urban area was minimum (268.4MWh) in the winter season, while the maximum (2632.4MWh) energy generation capacity was observed during the monsoon season. In the case of the industrial area, the minimum seasonal energy generation capacity was found to be $23.9 \mathrm{MWh}$ in winter while the maximum of $234.8 \mathrm{MWh}$ during the monsoon season. If solar panels installed on the proposed rooftops, an estimated energy potential of $5.9 \mathrm{GWh}$ would be generated in the study area.
\end{abstract}

Keywords: Geospatial Technology, Global Horizontal Irradiance, Photovoltaic, Rooftop

\section{INTRODUCTION}

Urban Population growth is rapidly increasing in India and after china India has second largest populated country in the world. In 2019 approximately $4 \%$ growth in power generation against $8 \%$ in electricity. With the increasing population, energy consumption growth rate will be $4.2 \%$ by the year 2035 (Mishra et al., 2020) In India electricity generating from the coal $74.0 \%$, hydro $9.3 \%$, natural gas $4.6 \%$, wind $3.3 \%$, bioenergy and waste $3.0 \%$, nuclear $2.5 \%$, solar $1.7 \%$, oil $1.6 \%$ (IEA). Therefore, to ensure energy security sustainably, it is crucial to escalating investments in alternative sustainable, clean, and pollution-free energy (Mann et al., 2015). To reduce the dependency on coal, government focused on sustainable source of energy. Mostly developed and developing countries generating electricity with renewable sources such as bio-energy, geothermal and solar energy in the recent years. In the year $2019,26 \%$ of global electricity generated from renewable resources (Firozjaei et al., 2019).

Jawaharlal Nehru National Solar Mission (JNNSM) had an initial target of $20 \mathrm{GW}$ by 2022 and then increased this target up to $28.18 \mathrm{GW}$ in March 2019 (Ministry of New and Renewable Energy, 2019). For the year 2021 -22 the target has been fixed for $6.5 \%$ of renewable energy consumption (Central Electricity Authority, 2019). As a developing nation, India has honoured its commitment towards consciousness for reducing the country's carbon footprint with Karnataka, Rajasthan, 
Andhra Pradesh, Tamil Nadu, and Gujarat are the leading solar energy-producing states. About $92 \%$ of solar energy in India is produced at utility-scale sites while only $8 \%$ is contributed by solar rooftop. The area utility data for solar power identifies rooftop as future potential sites to install new solar power plants (Kapoor et al., 2014).

Residential buildings energy consumptions is one of the key aspect for the energy management of urban areas (Mattoni et al., 2015), considering the primary energy consumption (PEC) and the renewable energy fraction (Noussan and Nastasi , 2018). Among renewables, solar energy is commonly the first energy source used in buildings to improve their energy sustainability and to reduce their consumptions of fossil fuels.

Singh and Banerjee (2015) estimated the roof top photovoltaic potential for Mumbai city using the available Land Use data. Comparison with sample daily load profiles shows that large scale deployment of Rooftop Solar Photovoltaic Systems can provide $12.8-20 \%$ of the average daily demand and $31-60 \%$ of the morning peak demand for different months, even with median conversion efficiency panels. Brito et al., (2019) also estimated urban solar energy potential by using LiDAR data and 3D models from 2D geometries was created in CityEngine. Nelson, and Grubesic,(2020) also found PVGIS, NERL and UAV data are used for the estimation of solar energy irradiance. Cheng et al., (2020) calculated solar energy potential for 10 cities and found annual solar irradiation ranges from 41.39 to 772.94 TWh, with an electric capacity of 6.21115.94 TWh.

In recent years, due to an emphasis on alternative energy sources, the assessment of solar energy potential has become an intensive area of research. Geographic Information System (GIS) has become an important and powerful tool to analyse regional renewable energy potential. Many researchers have specifically used GIS in the study of rooftop solar PV potential. A case study was carried out by Meenakshi et al., (2019) to estimate the solar energy potential on roof top of Government buildings in Karnal city using the geo spatial techniques. It was estimated that an amount of $264782.7 \mathrm{~kg}$ of Carbon dioxide $\left(\mathrm{CO}_{2}\right)$ is emitted during the production of $267457.2 \mathrm{kWh}$ electricity by the coal based power plant, and suggested to implement the installation of Solar PV systems on the digitized roof tops, so as to reduce the release of $\mathrm{CO}_{2}$.

\section{Need of the hour to Undertake the Study}

The Government of India has identified about 98 cities in the country to mitigate the increasing resources constrained urban areas under Smart Cities Mission to develop the infrastructure facilities with the help of information and communication technology. These Smart
Cities have been encouraged to meet about $10 \square 15 \%$ of respective energy demand from renewable energy resources, wherein solar energy can contribute significantly (Sharma et al., 2018).

The main focus of this study was to assess solar energy potential and electricity generation capacity in Karnal city by using the satellite data and geospatial technology.

\section{MATERIALS AND METHODS}

\section{Study area}

The Karnal city area situated in between $29^{\circ} 36^{\prime} 32.031$ to $29^{\circ} 41^{\prime} 8.947 " \mathrm{~N}$ latitude and $76^{\circ} 58^{\prime} 14.516^{\prime \prime}$ to 7659'19.176" E longitude with a geographical area of $90.40 \mathrm{~km}^{2}$ and comprises of 20 administrative wards (Fig. 1). The Karnal city is a warm city, least topographic variability and has a high potential for PV energy generation. The city receives an average temperature ranges $\left(38.8^{\circ} \mathrm{C}\right)$ high to $\left(7.5^{\circ} \mathrm{C}\right)$ minimum, (CLIMATEDATA.org) and the city is suitable for PV installations due to the least topographic variability.

\section{Data use and methodology}

The base map of Karnal city area with ward boundary was obtained from Municipal Corporation, Karnal, was digitised and given a proper projection system. In the present investigation, Sentinel-2 Satellite data (2019) having spatial resolution of $10 \mathrm{~m}$ were used for mapping the built-up areas after following the standard Geo referencing protocols using the ArcGIS 10.1 version. Apart from the Sentinel-2 data, World View-II satellite data, having a spatial resolution of $0.5 \mathrm{~m}$, were also used to extract the roads, vacant land, railway lines, canals etc., so as to eliminate the unwanted areas from the built up land. ALOS PALSAR DEM with $12.5 \mathrm{~m}$ resolution for the year 2019 used as an input for the estimation of $\mathrm{GHI}$ in the study area. ALOS PALSAR DEM used as input file and this is freely available at the USGS Earth Explorer portal.

Basically, the methodology involves the interpreting the satellite data for the building footprints, followed by the calculation of $\mathrm{GHI}$, the Geographic and Technical solar PV potential for Karnal city. The detailed process of methodology involved as described below:

\section{Spatio -temporal variation in global solar radiation}

The Ministry of New and Renewable Energy (MNRE) has been estimated in Indian 5000 trillion kWh of annual solar energy incident. Approximate $56 \%$ of the total Indian land area receives more than $5 \mathrm{kWh} / \mathrm{m}^{2} /$ day annual global radiations (Mahtta et al., 2014). The present study focused on assessment of solar energy potential on rooftop in urban area and to achieve this target estimates the monthly variation in $\mathrm{GHI}$ received in Karnal city.

For the estimation of the $\mathrm{GHI}$, the Solar Radiation tool 


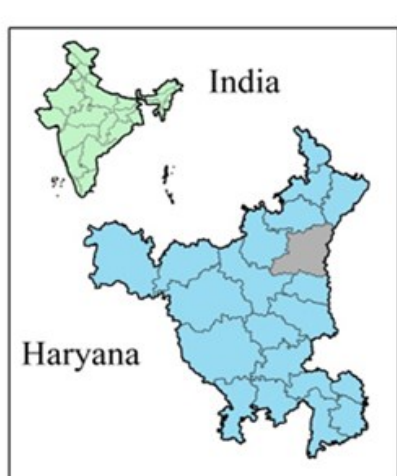

Karnal

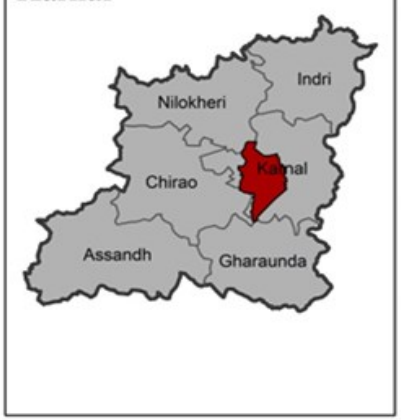

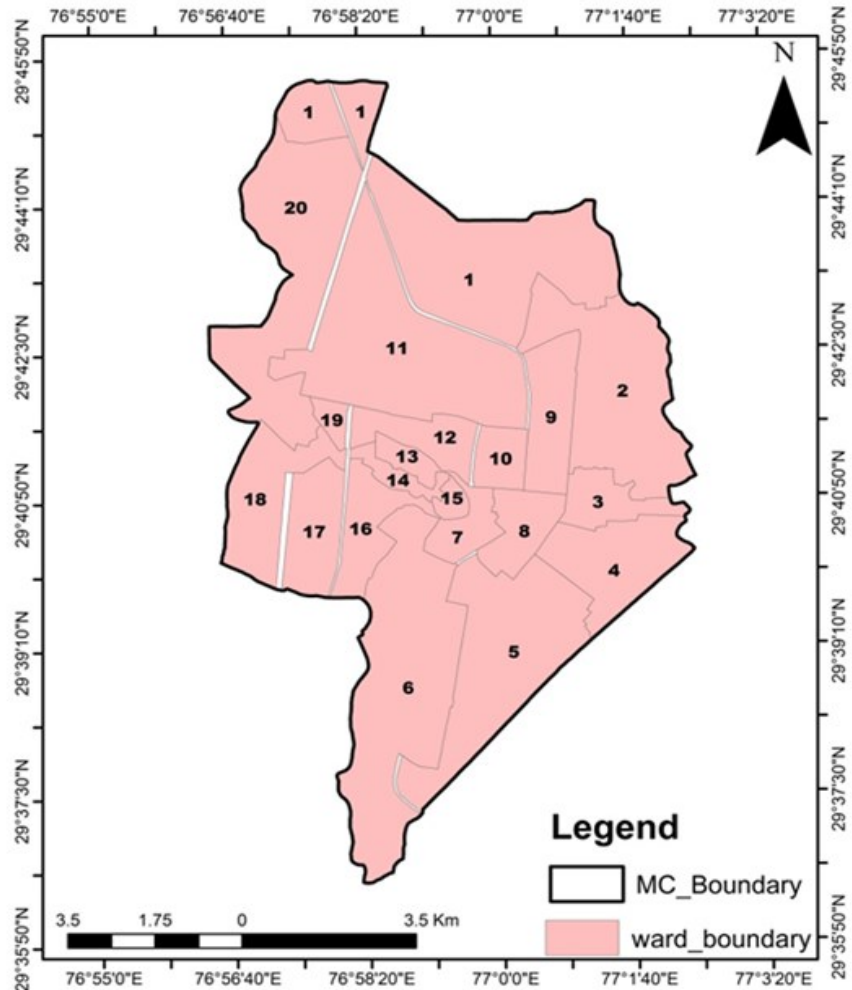

Fig. 1. Location map of study area with ward boundary.

set in ArcGIS software is used. This tool takes care of slope, elevation, orientation and atmospheric transmission as the most relevant inputs. The DEM of ALOS PALSAR, having all these parameters and was used as input raster, with a 200 sky size value as a default value (Kausika and Sark, 2021).

\section{Calculation of the geographical potential area for solar (G)}

Physical potential of rooftop area was calculated from the Sentinel 2 (resolution $10 \mathrm{~m}$ ) satellite data by supervised classification in ERDAS IMAGINE software. Builtup area was extracted by supervised classification. Rooftop area was estimated from the built-up area with the help of high resolution World View-II satellite data. Roads, Parks and vacant plot in urban area were removed.

Rooftop area calculated from the remote sensing may not always suitable for the installation of the PV panel. Some invariable factors like chimney, stairway and water tank on rooftop and shaded area not received direct solar radiation. Geographical potential area was estimated by using the following equation (Mishra et al., 2020).

Where

$$
G=A . I . H
$$

$\mathrm{G}=$ Geographical potential area

$A=$ Total rooftop area $\left(\mathrm{m}^{2}\right)$

$\mathrm{I}=$ Average solar radiation $\mathrm{kWh} / \mathrm{m}^{2} /$ day

$\mathrm{H}=$ Average sunshine hours is 8 in a day in study area. (https://www.worlddata.info/asia/india/climateharyana.php)

\section{Calculation of the technical energy output potential (E)}

Estimated electricity generation potential from the installed solar PV system is term as technical potential of the rooftop area. The equation used to calculate the estimated energy generation potential from PV system in the study area. This equation has been used by many other researchers also (Mahtta et al., 2014; Gastli and Charabi, 2010).

\section{Where}

$$
E=G \times r \times P R \times \eta \mathrm{TH}
$$

\section{$\mathrm{E}=$ Energy $(\mathrm{kWh})$}

$r=$ solar panel efficiency (range between 15 and 18\% default value used $=15 \%$, (Charfi et al., 2018; Gholami et al., 2018)

$\mathrm{PR}=$ Performance ratio it ranges between 0.5 and 0.9 (default value used $=0.75$ )

$\eta \mathrm{TH}=$ Temperature and irradiance losses (default value used $=0.9)($ Bergamasco and Asinari , 2011)

\section{RESULTS}

\section{Distribution of solar radiation}

Monthly and seasonal variation in solar radiation was calculated to estimate the solar energy potential in smart city Karnal is given in figure 2. A close perusal of this figure revealed that, the maximum radiation oc- 
curred in June and July months of the 2019 and while the minimum radiation occurs in December month. It was observed that the range of the solar radiation during 2019 was found to be $24-177 \mathrm{kWh} / \mathrm{m}^{2}$.

The solar insolation was observed as per the Indian seasons in Indian context, i.e., winter season (December to February), summer (March to May), monsoon (June to August) and post-monsoon (September to November) and shown as fig. 3. Further, it was observed that, maximum radiation was found during the monsoon season. During the winter season very less radiation reached to the surface because of high smog in the atmosphere.

\section{Estimation of geographical potential}

An attempt was made to map the ward-wise rooftop area of the study area (Fig. 4). The actual built-up area was calculated after eliminating the road network, riverbed area, and other features such as parks, stairscases and this feature eliminating work were done on the high-resolution world view-II satellite data. Table 1 depicts the identified urban and industrial areas. It was estimated that an area of $40.5 \mathrm{~km}^{2}$ ( $45 \%$ of TGA) was found to be under the built-up land category while an area of $3.33 \mathrm{~km}^{2}$ identified under Industrial and $37.2 \mathrm{~km}^{2}$ identified was under Urban. The ward numbers 1, 4,

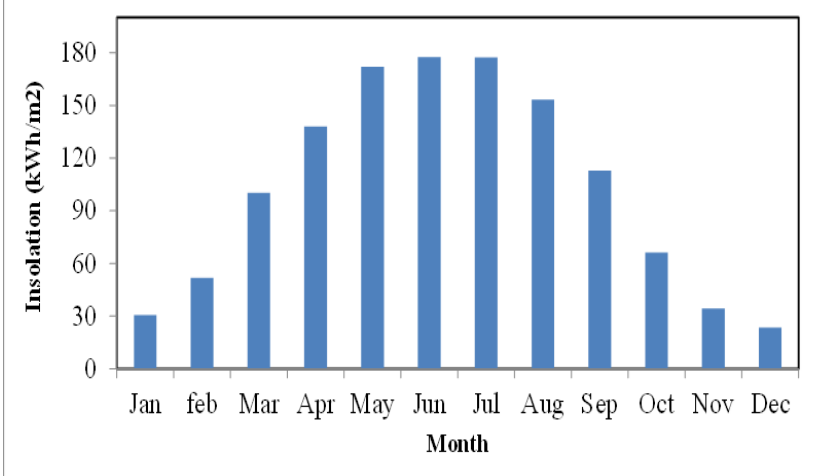

Fig. 2. Monthly variation in solar insolation in Karnal city $(\mathrm{GHI})$.

$5,6,11,18$ and 20 were under the mixed category, which comprised both urban and industrial, while the rest of the wards were purely urban and devoid of any industrial units.

During the ground truth verification it was observed that all the built-up rooftop area was not available for panel installation, because of the fact that it was being utilized for other purposes such as construction of water tank, stairs-cases, room, chimneys etc. apart from the parameter of shadow, so that $\left(12.2 \mathrm{~km}^{2}\right) 30 \%$ area of total built-up are considered as an available area for solar

Seasonal Insolation
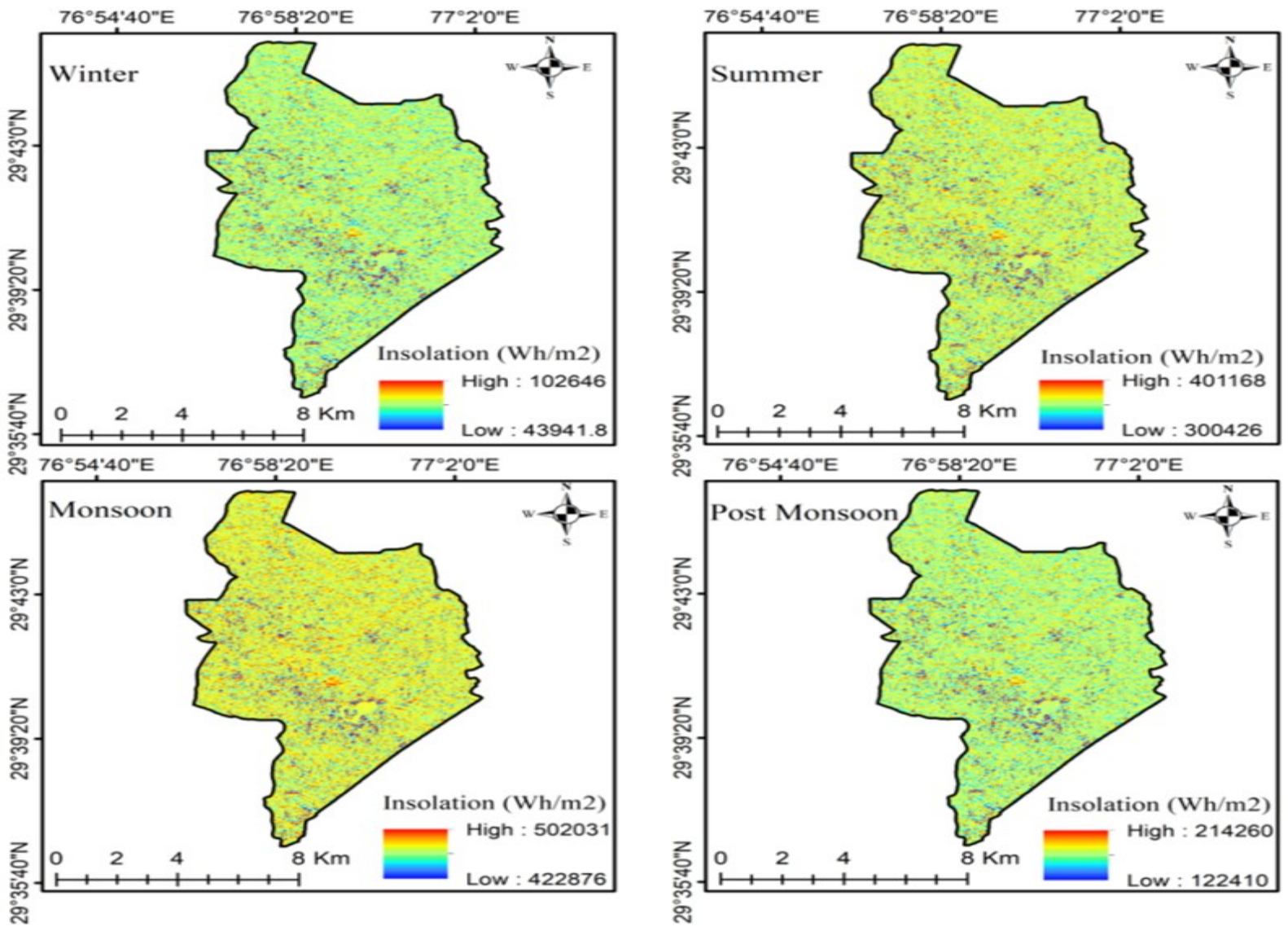

Fig. 3. Seasonal variation in solar insolation in the Karnal city. 


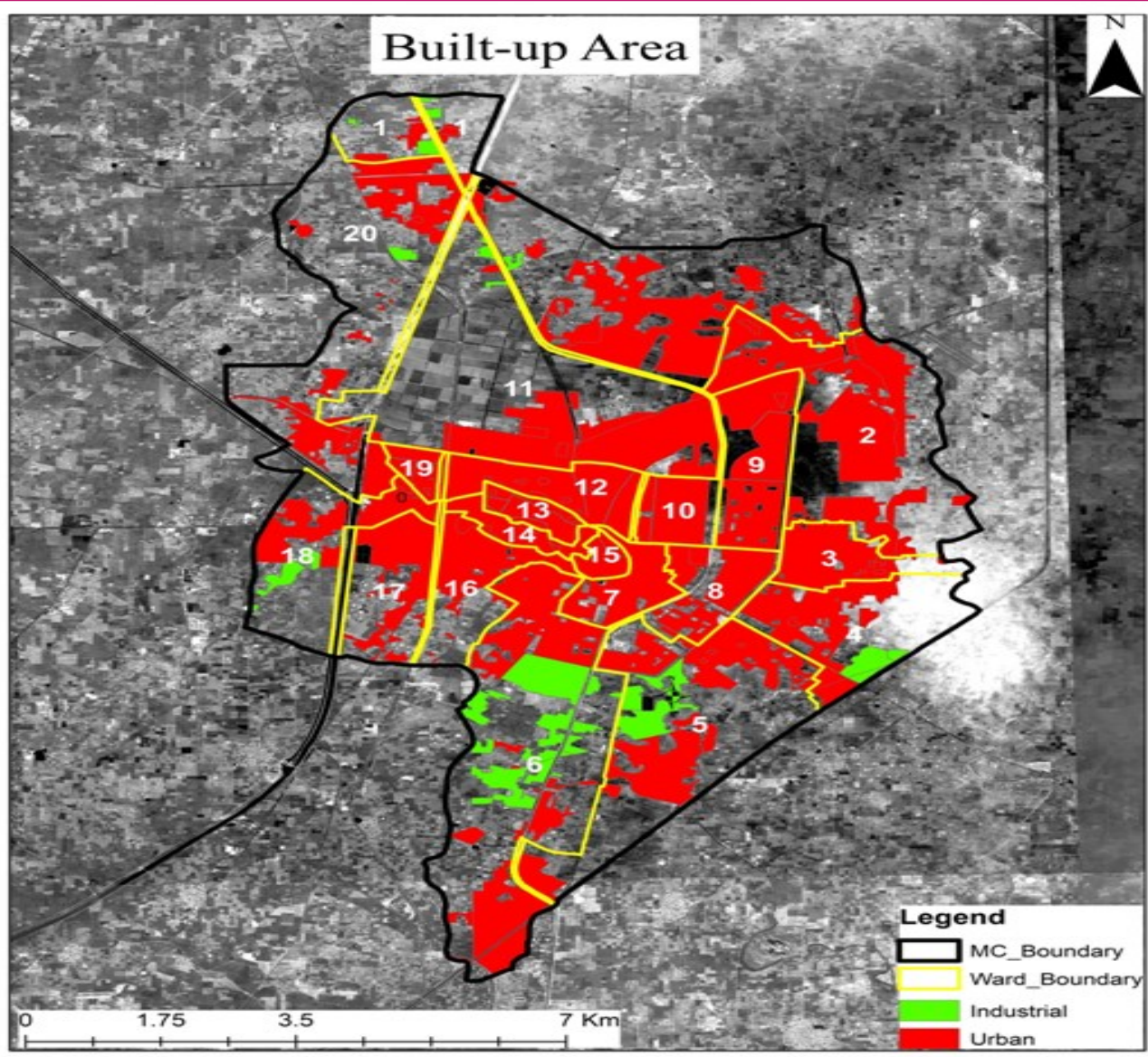

Fig. 4. Urban and Industrial built up areas of Karnal city as viewed by WV-II.

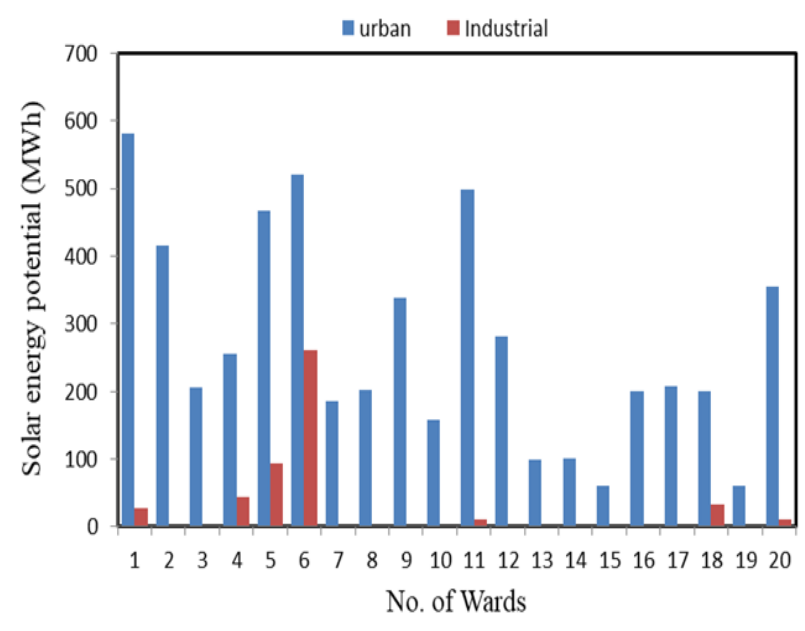

Fig.5 Ward wise solar energy potential in urban and industrial area.

panel installation. With the help of the remotely sensed data, and the DEM, we have calculated the average solar insolation for Karnal city and found to be $3.5 \mathrm{kWh} /$ $\mathrm{m}^{2} /$ day, out of which the minimum was found to be 0.79 $\mathrm{kWh} / \mathrm{m}^{2} /$ day, while the maximum was found to be 5.9 $\mathrm{kWh} / \mathrm{m}^{2} /$ day.

Karnal city had high energy demands because this is developing city of Haryana State. Utilization of the rooftop area for generating electricity by PV system can reduce the burden on energy generated from fossil fuel. Extra energy produced in the study area can also be economically fed to the grid to maintain buffer energy pool, to be utilized during power shortage.

\section{Estimation of technical potential}

The Solar panel efficiency (15\%), Performance ratio or the Conversion efficiency $(75 \%)$ and temperature and irradiance losses (0.9) are non-variable factors, whereas the rooftop area and $\mathrm{GHI}$ of in the study area are the variable factors. As the study area is very small, and topographically being flat in nature, the variations in the $\mathrm{GHI}$ is found to be very negligible, so that solar energy generation potential is directly proportional to area of rooftop.

Seasonal (average) variation in potential of generating solar energy was shown in Table 2 and Fig.5. We have taken $30 \%$ of built-up area in the study area amounting to be $12.16 \mathrm{~km}^{2}$ eliminating the areas under parks, stairs-cases, road network, river bed area etc.

It was estimated that the urban area has energy generation potential of $5393.3 \mathrm{MWh}(92 \%)$ and while the Industrial area had $481 \mathrm{MWh}(8 \%)$ potential. Further, a close perusal of table 4 had revealed that during, the (seasonal) energy generation capacity in urban area was found to be $268.4 \mathrm{MWh}$ (winter), and for summer 
Meenakshi, et al. / J. Appl. \& Nat. Sci. 13(2), 512 - 519 (2021)

Table 1.Total Built-up and available rooftop area for panel installation (Urban and Industrial built up area) in Karnal city (area in sq. kms).

\begin{tabular}{|c|c|c|c|c|c|c|}
\hline \multirow{3}{*}{$\begin{array}{l}\text { Ward } \\
\text { No. }\end{array}$} & \multirow{3}{*}{ Total area } & \multirow{3}{*}{$\begin{array}{l}\text { Built-up } \\
\text { Area }\end{array}$} & \multicolumn{4}{|c|}{ Built-up area } \\
\hline & & & \multicolumn{2}{|r|}{ Urban } & \multicolumn{2}{|r|}{ Industrial } \\
\hline & & & $\begin{array}{l}\text { Total } \\
\text { Area }\end{array}$ & $\begin{array}{l}\text { Available area } \\
\text { for panel installation }\end{array}$ & $\begin{array}{l}\text { Total } \\
\text { area }\end{array}$ & $\begin{array}{l}\text { Available area for } \\
\text { panel installation }\end{array}$ \\
\hline 1 & 12.41 & 4.21 & 4.01 & 1.20 & 0.20 & 0.06 \\
\hline 2 & 8.48 & 2.87 & 2.87 & 0.86 & Nil & Nil \\
\hline 3 & 1.79 & 1.42 & 1.42 & 0.43 & Nil & Nil \\
\hline 4 & 4.21 & 2.06 & 1.76 & 0.53 & 0.30 & 0.09 \\
\hline 5 & 8.63 & 3.87 & 3.22 & 0.97 & 0.65 & 0.20 \\
\hline 6 & 11.33 & 5.39 & 3.59 & 1.08 & 1.80 & 0.54 \\
\hline 7 & 1.42 & 1.28 & 1.28 & 0.38 & Nil & Nil \\
\hline 8 & 1.99 & 1.39 & 1.39 & 0.42 & Nil & Nil \\
\hline 9 & 2.95 & 2.33 & 2.33 & 0.70 & Nil & Nil \\
\hline 10 & 1.30 & 1.08 & 1.08 & 0.32 & Nil & Nil \\
\hline 11 & 11.13 & 3.51 & 3.43 & 1.03 & 0.08 & 0.02 \\
\hline 12 & 2.03 & 1.94 & 1.94 & 0.58 & Nil & Nil \\
\hline 13 & 0.71 & 0.68 & 0.68 & 0.20 & Nil & Nil \\
\hline 14 & 0.77 & 0.70 & 0.7 & 0.21 & Nil & Nil \\
\hline 15 & 0.44 & 0.42 & 0.42 & 0.13 & Nil & Nil \\
\hline 16 & 2.48 & 1.38 & 1.38 & 0.41 & Nil & Nil \\
\hline 17 & 2.81 & 1.43 & 1.43 & 0.43 & Nil & Nil \\
\hline 18 & 3.82 & 1.62 & 1.38 & 0.41 & 0.23 & 0.07 \\
\hline 19 & 0.51 & 0.42 & 0.42 & 0.13 & Nil & Nil \\
\hline 20 & 9.66 & 2.52 & 2.45 & 0.74 & 0.07 & 0.02 \\
\hline
\end{tabular}

Table 2. Seasonal Solar Energy potential (Urban and Industrial rooftops) in Karnal city.

\begin{tabular}{|c|c|c|c|c|c|c|c|c|}
\hline \multirow[b]{2}{*}{$\begin{array}{l}\text { Ward } \\
\text { No. }\end{array}$} & \multicolumn{4}{|c|}{ Urban potential (MWh) } & \multicolumn{4}{|c|}{ Industrial potential (MWh) } \\
\hline & Winter & Summer & Monsoon & $\begin{array}{l}\text { Post } \\
\text { monsoon }\end{array}$ & Winter & Summer & Monsoon & $\begin{array}{l}\text { Post } \\
\text { monsoon }\end{array}$ \\
\hline 1 & 28.94 & 193.55 & 283.76 & 75.12 & 1.41 & 9.43 & 13.82 & 3.66 \\
\hline 2 & 20.69 & 138.39 & 202.89 & 53.71 & $\mathrm{Nil}$ & Nil & Nil & Nil \\
\hline 3 & 10.22 & 68.39 & 100.26 & 26.54 & $\mathrm{Nil}$ & Nil & Nil & Nil \\
\hline 4 & 12.72 & 85.11 & 124.77 & 33.03 & 2.15 & 14.39 & 21.10 & 5.59 \\
\hline 5 & 23.26 & 155.58 & 228.09 & 60.38 & 4.69 & 31.39 & 46.02 & 12.18 \\
\hline 6 & 25.92 & 173.39 & 254.19 & 67.29 & 12.95 & 86.63 & 127.01 & 33.62 \\
\hline 7 & 9.23 & 61.71 & 90.47 & 23.95 & Nil & Nil & Nil & Nil \\
\hline 8 & 10.05 & 67.20 & 98.53 & 26.08 & $\mathrm{Nil}$ & Nil & Nil & $\mathrm{Nil}$ \\
\hline 9 & 16.81 & 112.42 & 164.81 & 43.63 & Nil & Nil & Nil & $\mathrm{Nil}$ \\
\hline 10 & 7.82 & 52.34 & 76.73 & 20.31 & $\mathrm{Nil}$ & Nil & Nil & $\mathrm{Nil}$ \\
\hline 11 & 24.78 & 165.74 & 242.98 & 64.32 & 0.54 & 3.63 & 5.32 & 1.41 \\
\hline 12 & 13.97 & 93.42 & 136.96 & 36.26 & Nil & Nil & Nil & $\mathrm{Nil}$ \\
\hline 13 & 4.90 & 32.79 & 48.07 & 12.72 & $\mathrm{Nil}$ & Nil & Nil & $\mathrm{Nil}$ \\
\hline 14 & 5.05 & 33.76 & 49.49 & 13.10 & Nil & Nil & Nil & Nil \\
\hline 15 & 3.05 & 20.37 & 29.87 & 7.91 & $\mathrm{Nil}$ & Nil & Nil & $\mathrm{Nil}$ \\
\hline 16 & 9.95 & 66.53 & 97.53 & 25.82 & Nil & Nil & Nil & Nil \\
\hline 17 & 10.35 & 69.22 & 101.49 & 26.87 & $\mathrm{Nil}$ & Nil & Nil & $\mathrm{Nil}$ \\
\hline 18 & 9.99 & 66.79 & 97.91 & 25.92 & 1.68 & 11.24 & 16.48 & 4.36 \\
\hline 19 & 3.06 & 20.44 & 29.97 & 7.93 & Nil & Nil & Nil & $\mathrm{Nil}$ \\
\hline 20 & 17.71 & 118.43 & 173.62 & 45.96 & 0.51 & 3.41 & 4.99 & 1.32 \\
\hline
\end{tabular}


season it was about 1756MWh followed by 2632.4 MWh (monsoon) and 696.9MWh (post monsoon). In case of industrial area the seasonal energy generation capacity was found to be $24 \mathrm{MWh}$ (winter), $160.1 \mathrm{MWh}$ (summer), 234.6 MWh (monsoon), 62.1MWh (post monsoon).

A close perusal of table 2 had revealed that the highest capacity of generation energy from solar panel during the monsoon and summer season and at the same period of year electricity demand is also high so this sustainable energy fill the gap in energy consumption and demand. In urban area highest potential found in Ward number 1 during complete year and in industrial area highest potential found in ward number 6 during all seasons.

\section{DISCUSSION}

The present research was carried to identify the potential solar of solar energy for the Karnal city (Haryana). The findings of the present study are with the conformal that of the others researchers.

Luqman et al. (2015) conducted a study to find out the solar energy potential (as an alternative source of energy) from the rooftops of residential areas in Lahore district of Pakistan, using the satellite data and GIS techniques and potential estimated was about 39,613,072 $\mathrm{kWh} / \mathrm{year}$. The estimated energy was found to be 9 times than the energy demand of the society, extra energy can be used in local /national electricity transmission grid. Solar PV energy would be supplement to compensate energy shortfall in local area. Assouline et al. (2017), carried out a study to estimate the rooftop solar PV potential for the urban areas at the commune level (the smallest administrative division) in Switzerland using the Support Vector Machines (SVMs) and Geographic Information System (GIS). The rooftop solar PV potential for a total 1901 out of 2477 communes in Switzerland was estimated. The results showed that, on an average, $81 \%$ of the total ground floor area of each building corresponds to the available roof area for the PV installation; the annual potential PV electricity production for the urban areas in Switzerland is estimated to be at $17.86 \mathrm{TW} \mathrm{h}$ (assumed $17 \%$ efficiency and $80 \%$ performance ratio). This amount corresponds to $28 \%$ of Switzerland's electricity consumption in 2015 . Sharma et al. (2018) used the IRS LISS satellite data and Very High Radiometer Resolution Radiometer (VHRR) data (KALPANA) in mapping the Rooftop area at 1:50,00 scale. They successfully estimated 10.02 GW of grid connected rooftops PV potential with 103.51 TWh of energy annually in the proposed 98 smart cities of India.

Though the present study confirms with these findings, we successfully attempted to identify the potential solar of solar energy at ward level in a Karnal city suing Sen- tinel 2 data, and augmented with World View-II panchromatic data. $\mathrm{CO}_{2}$ Emission Reduction Carbon contributes about $80 \%$ of all greenhouse gases which causes global warming (Lashof and Ahuja, 1990). As the Carbon emissions are increasing day by day, because of the increasing demand of energy, the alternate renewable energy technologies will definitely help to reduce Carbon emission as these technologies reduce less amount of $\mathrm{CO}_{2}$ than fossil fuels. The outputs of the study in the form of raster data (radiations output) and the vector data (building foot print) along with the estimated energy values will provide a baseline information for future studies to be undertaken in the field of solar energy estimations. Thus, the data generated in the present research will help in future study for the potentiality of carbon sequestration and mitigation of climate change at regional or at micro level. If all the roof areas utilized for solar PV panels installations, the energy generated would be huge $5.9 \mathrm{GWh}$ which can be used for the future requirements.

\section{Conclusion}

Geospatial technology plays an important role in estimation of solar energy potential on rooftop in the study area. The total geographical area of the municipal boundary of Karnal city was $90.4 \mathrm{Km}^{2} .45 \%\left(40.5 \mathrm{Km}^{2}\right)$ of the total area covered by urban $(41 \%)$ and industrial (4\%) built-up during 2019 . The total build-up area could not be available for solar panel installation because it might be utilized for water tank, stairs and other construction so that $30 \%$ area of the total built-up was considered a suitable area for panel installation. On the available area, solar insolation lied under 0.79-5.92 $\mathrm{kWh} / \mathrm{m}^{2} /$ day in a complete year and means solar insolation is $3.5 \mathrm{kWh} / \mathrm{m}^{2} /$ day. The total capacity of energy generation in the study area is $5.9 \mathrm{GWh}$ and out of this $8 \%$ potential had Industrial area and $92 \%$ urban area energy generation capacity from the solar photovoltaic system. Maximum potential of electricity generation is in monsoon and summer season. This work also helped to reduce $\mathrm{CO}_{2}$ production in the environment because coal based power plant has main source $\mathrm{CO}_{2}$ emission.

\section{ACKNOWLEDGEMENTS}

The first author (Meenakshi) is thankful to the Chairperson, Centre of Excellence for Energy and Environmental Studies, (CEEES) Deenbandhu Chhotu Ram University of Science and Technology, (DCRUST) for allowing to undertake the $\mathrm{Ph}$. D program at CEEES Department. The author also would like to thank the Director, Haryana Space Applications Centre (HARSAC), CCS HAU Campus, Hisar for providing the satellite data and infrastructure facilities to carry out the research program. 
Meenakshi, et al. I J. Appl. \& Nat. Sci. 13(2), 512 - 519 (2021)

\section{Conflict of interest}

The authors declare that they have no conflict of interest.

\section{REFERENCES}

1. Assouline, D., Mohajeri, N., \& Scartezzini, J. L. (2017). Quantifying rooftop photovoltaic solar energy potential: A machine learning approach. Solar Energy, 141, 278-296. http://dx.doi.org/10.1016/j.solener.2016.11.045

2. Bergamasco, L \& Asinari, P., (2011). Scalable methodology for the photovoltaic solar energy potential assessment based on available roof surface area: further improvements by ortho-image analysis and application to Turin (Italy). Sol. Energy, 85 (11), 2741-2756. https:// doi.org/10.1016/j.solener.2011.08.010

3. Brito, M. C., Redweik, P., Catita, C., Freitas, S., \& Santos, M. (2019). 3D solar potential in the urban environment: A case study in lisbon. Energies, 12 (18), 3457. https:// doi.org/10.3390/en12183457

4. Central Electricity Authority (2019), Central Electricity Authority Government of India Ministry of Power. https:// cea.nic.in/old/reports/annual/annualreports /annual_report -2020.pdf

5. Charfi, W., Chaabane, M., Mhiri, H., Bournot, P., (2018). Performance evaluation of a solar photovoltaic system. Energy Rep., 4, 400-406. https://doi.org/10.1016/j. egyr.2 018.06.004.

6. Cheng, L., Zhang, F., Li, S., Mao, J., Xu, H., Ju, W. \& Li, M. (2020). Solar energy potential of urban buildings in 10 cities of China. Energy, 196, 117038. https://doi.org/1 0.1016/j.energy.2020.117038

7. Firozjaei, M.K., Nematollahi, O., Mijani, N., Shorabeh, S.N., Firozjaei, H.K., \& Toomanian, A. (2019). An integrated GIS-based Ordered Weighted averaging analysis for solar energy evaluation in Iran: current conditions and future planning. Renew. Energy 136, 1130-1146. https:// doi.org/10.1016/j.renene.2018.09.090.

8. Gastli, A., \& Charabi, Y. (2010). Solar electricity prospects in Oman using GIS-based solar radiation maps. Renewable and Sustainable Energy Reviews, 14 (2), 790-797. doi:10.1016/j.rser.2009.08.018

9. Gholami, A., Khazaee, I., Eslami, S., Zandi, M., \& Akrami, E., (2018). Experimental investigation of dust deposition effects on photo-voltaic output performance. Sol. Energy 159, 346-352. https://doi.org/10.1016/j.solener.20 17.11.0 10.

10. Kausika, B. B., \& van Sark, W. G. (2021). Calibration and Validation of ArcGIS Solar Radiation Tool for Photovoltaic Potential Determination in the Netherlands. Energies, 14 (7), 1865. doi.org/10.3390/en14071865

11. Kapoor, K., Pandey, K.K., Jain, A.K., \& Nandan, A. (2014). Evolution of solar energy in India: a review. Renew. Sustain. Energy Rev., 40, 475-487. https:// doi.org/10.1016/j. rser.2014.07.118.
12. Lashof, D.A. \& Ahuja, D.R. (1990) Relative Contributions of Greenhouse Gas Emissions to Global Warming. Nature, 344, 529-531. http://dx.doi.org/10.1038/344529a0

13. Luqman, M., Ahmad, S. R., Khan, S., Ahmad, U., Raza, A., \& Akmal, F. (2015). Estimation of solar energy potential from rooftop of Punjab government servants cooperative housing society Lahore using GIS. Smart Grid and Renewable Energy, 6(05), 128. http://www.scirp.org/ journal/sgre http://dx.doi.org/10.4236/sgre.2015.65012

14. Mahtta, R., Joshi, P. K., \& Jindal, A. K. (2014). Solar power potential mapping in India using remote sensing inputs and environmental parameters. Renewable Energy, 71, 255-262. https://doi.org/10.1016/j.renene.2014.05.037

15. Mann, C.C., (2015). Solar or Coal? the Energy India Picks May Decide Earth's Fate. Wired. Retrieved from. https:// www.wired.com/2015/11/climate-cha nge-in-india/.

16. Mattoni, B., Pagliaro, F., Gugliermetti, L., Bisegna, F., \& Cellucci, L. (2015). A territorial based strategy for the distribution of sensor networks in smart cities. IEEE 15th International Conference on Environment and Electrical Engineering (EEEIC), 653-658. https://doi.org/10.1109/ EEEIC.2015.7165242

17. Meenakshi, Kumar, K. E., \& Kumari, N. (2019). Estimation of Photovoltaic Energy Potential and Reduced Carbon Emission through Geo-Spatial Technology-A Case Study of Karnal City, Haryana (India).In Proceedings of International Conference on Sustainable Computing in Science, Technology and Management (SUSCOM), Amity University Rajasthan, Jaipur-India, 2213-2219.

18. Mishra, T., Rabha, A., Kumar, U., Arunachalam, K., \& Sridhar, V. (2020). Assessment of solar power potential in a hill state of India using Remote Sensing and Geographic Information System. Remote Sensing Applications: Society and Environment, 19, 100370. https://doi.org/10.1016/ j.rsase.2020.100370

19. Ministry of New and Renewable Energy (2017). Ministry of New and Renewable Energy (MNRE), Government of India, New Delhi. www.mnre.gov.in.

20. Nelson, J. R., \& Grubesic, T. H. (2020). The use of LiDAR versus unmanned aerial systems (UAS) to assess rooftop solar energy potential. Sustainable Cities and Society, 61, 102353. https://doi.org/10.1016/j.scs.2020.102353

21. Noussan, M., \& Nastasi, B. (2018). Data analysis of heating systems for buildings - A tool for energy planning, policies and systems simulation. Energies, 11(1), 233. https://doi.org/10.3390/en11010233

22. Sharma, S., Jain, G., Mishra, S., \& Bhattacharya, B., (2018). Assessment of roof-top solar energy potential in proposed smart cities of india. Conference: Asian Conference of Remote Sensing, New Delhi, India.(PDF) Assessment of Roof-Top Solar Energy Potential In Proposed Smart Cities Of India (researchgate.net)

23. Singh, R., \& Banerjee, R. (2015). Estimation of rooftop solar photovoltaic potential of a city. Solar Energy, 115, 589-602. https://doi.org/10.1016/j.solener.2015.03.016 